\title{
Comparative in vitro study of the shear bond strength of brackets bonded with restorative and orthodontic resins
}

\begin{abstract}
Hassan Isber ${ }^{(a)}$
Aldrieli Regina Ambrosio(b)

Paulo Eduardo Guedes Carvalho(c)

Karyna Martins do Valle-Corotti(c)

Danilo Furquim Siqueira ${ }^{(c)}$
\end{abstract}

(a) Department of Orthodontics, SOEPAR Sindicato dos Odontologistas do Paraná, Curitiba, PR, Brazil.

(b) Department of Orthodontics, Araraquara School of Dentistry, UNESP - Univ Estadual Paulista, Araraquara, SP, Brazil.

(c)Department of Orthodontics, UNICID University of São Paulo City, São Paulo, SP, Brazil.

Corresponding author:

Hassan Isber

Avenida Silva Jardim, 3455

Curitiba - PR - Brazil

CEP: 80240-021

E-mail: hassan@neo.odo.br

Received for publication on Aug 12, 2010 Accepted for publication on Oct 11, 2010

\begin{abstract}
The aim of this study was to evaluate the shear bond strength of brackets bonded with different restorative systems and compare it with that afforded by an established orthodontic bonding system. Seventy human bicuspids were used, divided into five different groups with 14 teeth each. Whereas a specific orthodontic bonding resin (Transbond ${ }^{\mathrm{TM}} \mathrm{XT}$ ) was used in the control group, the restorative systems Charisma, Tetric Ceram, TPH Spectrum and Z100 were used in the other four groups. Seven days after bonding the brackets to the samples, shear forces were applied under pressure in a universal testing machine. The data collected was evaluated using the ANOVA test and, when a difference was identified, the Tukey test was applied. A 5\% level of significance was adopted. The mean results of the shear bond strength tests were as follows: Group 1 (Charisma), $14.98 \mathrm{MPa}$; Group 2 (Tetric Ceram), $15.16 \mathrm{MPa}$; Group 3 (TPH), $17.70 \mathrm{MPa}$; Group 4 (Z100), $13.91 \mathrm{MPa}$; and Group 5 or control group (Transbond ${ }^{\mathrm{TM}} \mathrm{XT}$ ), $17.15 \mathrm{MPa}$. No statistically significant difference was found among the groups. It was concluded that all tested resins have sufficient bond strength to be recommended for bonding orthodontic brackets.
\end{abstract}

Descriptors: Orthodontics; Shear Strength; Orthodontic Brackets; Dental Cements; Dental Bonding.

\section{Introduction}

Since the 1960s, when the first studies on bonding techniques for bonding brackets to the tooth surface were conducted, innumerable scientific advancements have been made to improve the techniques. ${ }^{1}$ The procedure of acid etching of the tooth surface, proposed by Buonocore, ${ }^{2}$ enabled an increase in the mechanical bond between the enamel surface and the resinous restorative material, which is afforded by the mechanical interlocking of the resin into the microporosities produced by the phosphoric acid etching.

The improvement in light-activated resins benefitted resins designed for both restorative dentistry and orthodontic bracket bonding. At present, there are several resinous systems on the market intended specifically for bonding orthodontic accessories, and scientifically proven to be effective. ${ }^{3-9}$ However, although orthodontic adhesives have a basic formula similar to that of resin composites commonly used in clinical restorative procedures, they are more expensive and are commercially available only 
from suppliers dealing exclusively with orthodontic materials. For this reason, and possibly also because of their different consistency, not all professionals are familiar with their use and do not choose to use them on a regular basis.

Hence, because there composition is similar to that of resins designed for restorations, and because the latter are less costly, and have greater variety and availability, the aim of the present study was to measure and compare the shear bond strength values obtained with these two types of materials. There are a great number of adhesive systems established on the market for orthodontic use. The choice of the Transbond ${ }^{\mathrm{TM}} \mathrm{XT}$ orthodontic adhesive system for the control group was based on the results of several studies confirming its effectiveness, and also on the fact that it is frequently used as a reference when other systems are evaluated. ${ }^{5,9-17}$ It would therefore be possible to assess whether the restorative systems tested could be considered acceptable in terms of the minimum strength requirements for satisfactory orthodontic bonding.

The aims of this study were thus to assess and compare the shear bond strength of the four restorative systems tested and determine whether they could be used for orthodontic bracket bonding, as well as to compare their bond strength values with those obtained with an orthodontic adhesive system already established on the market.

\section{Materials and Methods}

This study was approved by the Institutional Research Ethics Committee. The study sample consisted of 70 human premolar teeth obtained from a regularly constituted dental school tooth bank. The criteria for selecting the teeth were the absence of caries and the integrity of the buccal aspect of the crown onto which the brackets were to be bonded.

The teeth, divided into five groups of 14 each, received metal Edgewise brackets (TP Orthodontics, La Porte, USA), which were bonded with different light-cured resin composites. In Groups 1 through 4 , the brackets were bonded with resins originally developed for restorative procedures; in Group 5, a resin system manufactured for the specific purpose of bonding orthodontic brackets was used, representing the control group. Before applying the different resins, the adhesive systems specific to each resin composite were applied following each manufacturer's recommendations.

Table 1 shows the composition of the resin composite and corresponding adhesive system used in

Table 1 - Commercial brand, manufacturer and composition of the resin composites and respective adhesive systems (primers) used in the study.

\begin{tabular}{|c|c|c|c|c|c|}
\hline Group & Resin Composite & Adhesive System & Manufacturer & Origin & Composition \\
\hline 1 & Charisma & Gluma & Heraeus Kulzer & $\begin{array}{l}\text { Gonsennheumer, } \\
\text { Germany }\end{array}$ & $\begin{array}{l}\text { Bis-GMA resin, modified urethane, boron, } \\
\text { aluminum silicate and silanized barium, silanized } \\
\text { pyrolytic silica, camphorquinone, EDAB, butylated } \\
\text { hydroxytolvene, mineral dyes }\end{array}$ \\
\hline 2 & Tetric Ceram & Excite & Ivoclar Vivadent & $\begin{array}{l}\text { Schaan, } \\
\text { Liechtenstein }\end{array}$ & $\begin{array}{l}\text { Bis-GMA resin, urethane dimethacrylate and } \\
\text { triethylene glycol, barium, ytterbium trifluoride, } \\
\text { barium and aluminum fluorsilicate glass, silicone } \\
\text { dioxide, spherical mixed oxides, catalyzers, } \\
\text { stabilizers }\end{array}$ \\
\hline 3 & TPH Spectrum & $\begin{array}{l}\text { Prime \& Bond } \\
\quad 2.1\end{array}$ & Dentsply & $\begin{array}{l}\text { Rio de Janeiro, } \\
\text { Brazil }\end{array}$ & $\begin{array}{l}\text { Bis-GMA resin, modified urethane, boron, } \\
\text { aluminum silicate and silanized barium, silanized } \\
\text { pyrolytic silica, camphorquinone, EDAB, butylated } \\
\text { hydroxytolvene, mineral dyes }\end{array}$ \\
\hline 4 & Z 100 & $\begin{array}{l}\text { Adper Single } \\
\quad \text { Bond } 2\end{array}$ & 3M Espe & St. Paul, USA & $\begin{array}{l}\text { Bisthymol-aglycidyl dimethacrylate (Bis-GMA), } \\
\text { triethylene glycol dimethacrylate (TEDGMA), } \\
\text { zirconium, silica }\end{array}$ \\
\hline 5 & Transbond $^{\text {'" }}$ XT & $\begin{array}{l}\text { Transbond } \\
\text { Primer }\end{array}$ & 3M Unitek & St. Paul, USA & $\begin{array}{l}\text { Bis-GMA resin, silane, n-dimethyl benzocaine, } \\
\text { hexa-fluoride-phosphate }\end{array}$ \\
\hline
\end{tabular}


each group.

All bicuspids used in this study were sectioned transversely with a multi-blade bur (SS White, Lakewood, USA) at high speed and under ample cooling with water spray, so that they could be inserted, one by one, into segments of a 3/4-inch PVC pipe (Tigre, Joinville, Brazil) that had been cut into rings measuring approximately $1 \mathrm{~cm}$ each. They were fixed inside the pipe segments with a chemically activated acrylic resin, Orthoclass (Artigos Odontológicos Clássico Ltda, São Paulo, Brazil), and only the buccal aspect of each tooth remained exposed. They were then stored in distilled water.

Before bracket bonding, the teeth were submitted to prophylaxis with pumice stone and water for 10 seconds and then washed with water jets to remove the pumice stone paste completely. All the teeth were etched with $37 \%$ phosphoric acid (Villevie, Joinville, Brazil) for 30 seconds.

The adhesive and resinous products were manipulated in accordance with the respective manufacturers' instructions, strictly following the steps described for each material. Afterwards, the materials were applied to the bracket bases so as to cover them completely and uniformly. Each bracket was placed in the middle third of the tooth crown, centralized in the mesiodistal direction and parallel to the long axis of the crown. They were pressed down until a standardized composite thickness was obtained under the brackets to prevent bond strength variation. ${ }^{18}$ The excess material around the bracket was removed with a dental explorer probe. A duly calibrated, visible light-curing unit that uses a halogen lamp (Optilux II) (Gnatus Equipamentos MédicoOdontológicos Ltda, Ribeirão Preto, Brazil) was activated at a $5-\mathrm{mm}$ distance from the buccal surface of the crowns, in the cervical and incisal regions of each bracket for 20 seconds per region, totaling 40 seconds per bracket.

After the bonding procedure, the specimens were placed in a closed receptacle containing distilled water at room temperature for a period of seven days, for the purposes of achieving the final bond strength obtained through the bracket bonding procedure ${ }^{19}$ and guaranteeing complete hydration of the materials involved in the experiment. ${ }^{20,21}$ After this period, the specimens were submitted to shear testing, during which all the procedures were performed by the same operator in the same laboratory.

The shear test was performed by compression of a metal blade adapted to the mobile arm of a Kratos mechanical test machine, model K2000 (Kratos Equipamentos Industriais Ltda, São Paulo, Brazil) (Figure 1). The blade generated pressure perpendicular to the bonding line between the bracket and the tooth. A load cell of $50 \mathrm{kgf}$ was used at a speed of $0.5 \mathrm{~mm}$ per minute, until the device was completely displaced from the tooth surface.

The shear bond strength data of each specimen was provided by the test machine in a computerized format. To analyze the data and make a comparison among the groups, the Tukey test for multiple comparisons was applied at a level of significance of $5 \%$.

\section{Results}

Table 2 shows the descriptive statistics of the 5 groups studied. Group 3 showed the highest mean strength $(17.70 \pm 4.68 \mathrm{MPa})$, followed by Group 5 (17.15 \pm 3.18$)$. The lowest mean bond strength was obtained in Group 4 (13.91 \pm 3.88$)$.

In Graph 1, box plots depict the shear bond

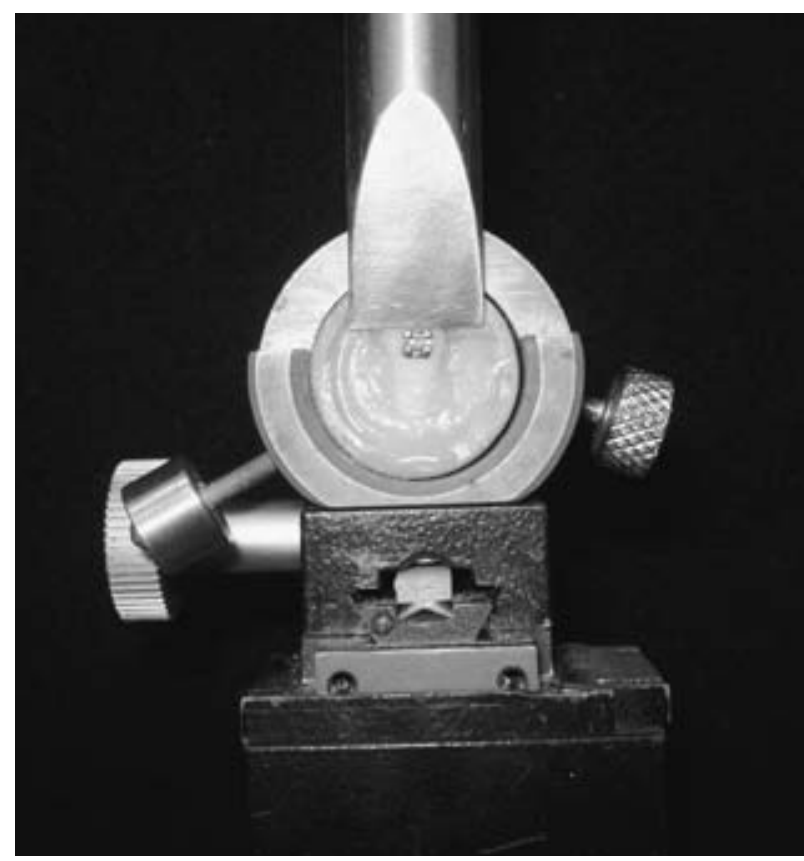

Figure 1 - Shear test by compression of a metal blade adapted to the mobile arm of the test machine. 
Table 2 - Descriptive statistics of the shear bond strength values $(\mathrm{MPa})$ obtained for the experimental groups.

\begin{tabular}{l|c|c|c|c|c}
\hline \multicolumn{1}{c|}{ Group } & N & Mean & Standard Deviation (SD) & Minimum & Maximum \\
\hline $1-$ Charisma & 14 & 14.86 & 2.67 & 10.58 & 18.94 \\
\hline 2- Tetric Ceram & 14 & 15.16 & 3.34 & 11.09 & 23.54 \\
\hline 3- TPH Spectrum & 14 & 17.70 & 4.68 & 8.02 & 25.59 \\
\hline $4-$ Z100 & 14 & 13.91 & 3.88 & 5.89 & 19.45 \\
\hline $5-$ Transbond XT & 14 & 17.15 & 3.18 & 10.41 & 22.09 \\
\hline
\end{tabular}

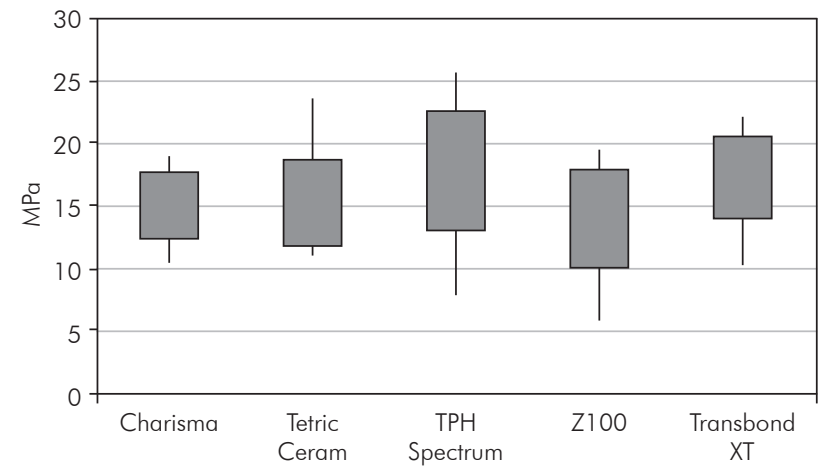

Graph 1 - Box plot of the shear bond strength values obtained according to the experimental group.

strength values obtained for the experimental groups. Note that Groups 1 and 2 show less dispersion, and, although Group 3 shows a higher mean, it is the one that had the highest dispersion.

After applying the Shapiro-Wilk normality test and confirming the occurrence of a normal distribution (p-value: 0.9956 ), the Tukey multiple comparisons test was applied to identify possible significant differences among the groups (Table 3). As shown in Table 3, there was no significant difference between the groups at a level of $5 \%$.

\section{Discussion}

According to Reynolds, ${ }^{21}$ the minimum acceptable shear bond strength values of orthodontic appliances range between $5.8 \mathrm{MPa}$ and $7.8 \mathrm{MPa}$. The results of the present study confirmed this expectation for all the resins assessed. The maximum shear bond strength value of $25.59 \mathrm{MPa}$ was observed in Group 3 (TPH Spectrum), and the minimum individual values were observed in Groups 3 (TPH Spectrum) and 4 (Z100), respectively $8.02 \mathrm{MPa}$ and $5.89 \mathrm{MPa}$, thus confirming that they can be safely indicated for bonding orthodontic appliances.
Table 3 - Tukey test results for the comparison made among the study groups.

\begin{tabular}{l|c|c}
\hline \multicolumn{1}{c|}{ Comparison } & Difference & p-value \\
\hline Charisma $\times$ Tetric Ceram & 0.00 & 1.0000 \\
\hline Charisma x TPH Spectrum & 2.83 & 0.2468 \\
\hline Charisma x Z100 & -0.95 & 0.9570 \\
\hline Charisma x Transbond XT & 2.29 & 0.4608 \\
\hline Tetric Ceram x TPH Spectrum & 2.83 & 0.2478 \\
\hline Tetric Ceram x Z100 & -0.95 & 0.9565 \\
\hline Tetric Ceram x Transbond XT & 2.28 & 0.4621 \\
\hline TPH Spectrum $\times$ Z100 & -3.78 & 0.0558 \\
\hline TPH Spectrum x Transbond XT & -0.55 & 0.9945 \\
\hline Z100 x Transbond XT & 3.24 & 0.1391 \\
\hline
\end{tabular}

After the shear test was performed and the values obtained were compared with those of the control group (Transbond XT), it was found that the behavior of the groups was statistically similar and that the values obtained were always above the minimum requirements, rendering all of the resins assessed suitable for use in orthodontic bonding. The mean shear bond strength values ranged from 13.91 MPa (Group 4 - Z100) to $17.7 \mathrm{MPa}$ (Group 3 - TPH), but those groups where extreme values were observed were also those with the highest dispersion of data, indicating the absence of a statistical difference between the results.

When assessing five different adhesive systems used in Orthodontics, Souza et al. ${ }^{10}$ obtained a mean shear bond strength value of $19.93 \mathrm{MPa}$ for Transbond XT, differing from the result obtained by Correr Sobrinho et al., ${ }^{11}$ who found a mean value of 7.33 MPa for the same resin.

Since size and form differences in the bracket base may affect the shear bond strength values obtained, ${ }^{17}$ studies using the same brand and type of 
brackets should be considered for comparison with the results obtained in the present study.

Regarding bracket brand, Vasques et al. ${ }^{12}$ used TP Orthodontics, the same used in this study, also combined with Transbond ${ }^{\mathrm{TM}}$ XT orthodontic adhesive. In Vasques' study, the mean shear bond strength value obtained for Transbond ${ }^{\mathrm{TM}} \mathrm{XT}$ was 10.72 $\mathrm{MPa}$, which is acceptable for bonding, but lower than both the $14.92 \mathrm{MPa}$ found by Lugato et $a .^{22}$ and the mean found in the present study (17.15 MPa).

Despite the wide range of studies on different aspects related to the direct bonding of orthodontic accessories, there are few studies in the literature about the use of restorative systems for bonding orthodontic accessories. ${ }^{6,9}$ Nonetheless, adhesive systems similar to orthodontic systems, such as flow systems, were compared with the Transbond ${ }^{\mathrm{TM}} \mathrm{XT}$ orthodontic resin, and the results indicated no statistical differences in shear bond strength for most of the systems tested, and no increase in the bonding failure rates. ${ }^{23}$

In a comparative study with several systems, Correr Sobrinho et al. ${ }^{11}$ compared Z100 restorative resin with Transbond ${ }^{\mathrm{TM}}$ XT. When performing the shear test, they concluded that Transbond XT showed higher shear bond strength values (7.33 MPa) when compared with Z100 (6.16 MPa), but there were no statistical differences. Despite the difference in the intensity of values, probably because of the application of different shear testing methods, the findings of this study also showed the same statistical similarity between Transbond ${ }^{\mathrm{TM}}$ XT resin and other restorative systems.

In another study, Correr Sobrinho et al. ${ }^{6}$ confirmed the successful use of Z100 for orthodontic bonding. Mondelli and Freitas ${ }^{9}$ also tested Z250, as one of the resins used in their study. Ødegaard and Segner ${ }^{24}$ reported that, at the beginning of their research, owing to the lack of specific light-activated adhesives for orthodontic bonding, they used restorative systems with satisfactory results. At that time, the authors already indicated the possibility of using restorative systems in orthodontic bonding, in agreement with the results of the present study.

The standard deviations found in this study varied between 2.67 and 4.68 , suggesting the existence of a balance between the groups, and showing greater reliability in the standardization of the methods used. This study showed adhesive systems with mean bond strength values sometimes higher than those needed for good bonding, although the difference was not statistically significant.

In our study, although Group 3 (TPH Spectrum) showed the highest mean bond strength $(17.70 \mathrm{MPa})$, it was also the group that showed the greatest intra-group divergence in the results $(8.02 \mathrm{MPa}$ and $25.59 \mathrm{MPa})$. If we consider that extremely high values may create future bracket removal difficulties, and that lower values, on the other hand, may favor accidental bracket debonding, homogenous intra-group results could represent a more suitable parameter for material choice. This rationale is particularly valid for the five resins tested in the present study, which are all adequate for use in Orthodontics in terms of shear bond strength minimum values. Sufficient and similar bond strength values among the brackets bonded with a given adhesive is thus a desirable property in orthodontic clinical practice. Although Group 1 showed the second lowest mean $(14.86 \mathrm{MPa})$, it also showed the lowest dispersion of values (minimum of $10.58 \mathrm{MPa}$ and maximum of $18.94 \mathrm{MPa})$. Hence, from this point of view, Group 1 represents a good choice for clinical use in Orthodontics.

It is noteworthy to mention that there are several other factors influencing the professional's choice of bonding materials for orthodontic use, such as cost, availability, handling experience with the product, and working consistency, among others. This study assessed only one aspect of these adhesive systems (shear bond strength) in which all the groups were shown to behave in a statistically similar manner and, from a clinical point of view, were all compatible with an orthodontic application.

It is equally important to stress that to obtain proper shear bond strength values, irrespective of the material considered, the orthodontist must be careful when performing the operative technique, strictly observing the instructions and recommendations of the manufacturer of each material used. 


\section{Conclusions}

Based on the method adopted in this study and in accordance with the results obtained, it was concluded that:

- All four restorative systems assessed presented statistically similar shear bond strength values, all of which are compatible with the orthodontic

\section{References}

1. Newman GV. Epoxy adhesives for orthodontics attachments: Progress report. Am J Orthod. 1965 Dec;51(12):901-12.

2. Buonocore MG. A simple method of increasing the adhesion of acrylic filling materials to enamel surface. J Dent Res. 1955 Dec;34(6):849-53.

3. Miura F, Nakagawa K, Masuhara E. New direct bonding system for plastic brackets. Am J Orthod. 1971 Apr;59(4):35061.

4. O’Brien KD, Read MJF, Sandison RJ, Roberts CT. A visible light-activated direct-bonding material: an in vivo comparative study. Am J Orthod Dentofacial Orthop.1989 Apr;95(4):34851.

5. Wang WN, Meng CLA. A study of Bond strength between light and self-cured orthodontic resin. Am J Orthod Dentofacial Orthop. 1992 Apr;101(4):350-4.

6. Correr Sobrinho L, Correr GM, Consani S, Sinhoreti MAC, Consani RLX. Influência do tempo pós-fixação na resistência ao cisalhamento de braquetes colados com diferentes materiais. Pesqui Odontol Bras. 2002 Jan-Mar;16(1):43-9.

7. Grando PR, Magnani MBBA, Pereira AC, Meneguim MC, Kuramae M, Tavares S. Colagem de bracket ortodôntico com resina composta e com ionômero de vidro. J Bras Ortodon Ortop Facial. 2002 Mar-Abr;7(38):118-24.

8. Pithon MM, Santos RL, Oliveira MV, Ruellas ACO. Estudo comparativo in vitro da resistência ao cisalhamento da colagem e do índice de remanescente adesivo entre os compósitos Concise e Fill Magic. Rev Dent Press Ortodon Ortopedi Facial. 2006 Jul-Ago;11(4):76-80.

9. Mondelli AL, Freitas MR. Estudo comparativo da resistência adesiva da interface resina braquete, sob esforços de cisalhamento, empregando três resinas compostas e três tipos de tratamento na base do braquete. Rev Dent Press Ortodon Ortopedi Facial. 2007 Maio-Jun;12(3):111-25.

10. Souza CS, Francisconi PAS, Araújo. PA. Resistência de união de cinco cimentos utilizados em ortodontia. Rev Fac Odontol Bauru. 1999 Jan-Jun;7(1/2):15-21.

11. Correr Sobrinho L, Consani S, Sinhoretti MAC, Correr GM, Consani RLX. Avaliação da resistência ao cisalhamento na colagem de braquetes, utilizando diferentes materiais. Rev Assoc Bras Odontol. 2001 Jun-Jul;9(3):157-62. application of accessory bonding.

- All four restorative systems tested showed shear bond strength values statistically compatible with the bond strength presented by an orthodontic adhesive system established on the market.

12. Vasques WO, Ciruffo PSD, Tubel CAM, Miyamura ZY, Vedovello FM. Resistência ao cisalhamento de diferentes braquetes metálicos. Rev Gaucha Odontol. 2005 Jul-Set;53(3):186-90.

13. Onofre NML, Retamoso LB, Marchioro EM, Berthold TM. Atuação da luz halógena e do LED na resistência de união de braquetes colados no esmalte dentário humano. Rev Odonto Cien. 2007 Jul-Set;22(57):238-42.

14. Tortamano A, Nauff F, Naccarato SRF, Vigorito JW. Avaliação da força de tração em braquetes colados pela técnica indireta com diferentes sistemas de adesão. Rev Dent Press Ortodon Ortopedi Facial. 2007 Maio-Jun;12(3):104-10.

15. Pithon MM, Oliveira MV, Santos RL, Bolognese AM, Ruellas ACO. Avaliação in vitro da resistência ao cisalhamento e liberação de flúor de dois cimentos de ionômero de vidro reforçado por resina. Rev Odonto Cien. 2007 Out-Dez;22(58):305-7.

16. Lowder PD, Foley T, Banting DW. Bond strength of 4 orthodontic adhesives used with a caries-protective resin sealant. Am J Orthod Dentofacial Orthop. 2008 Aug;134(2):291-5.

17. Chapman JL, Coreil MN, Armbruster PC, Du JX. Shear bond strengths of molar tubes bonded with different adhesives. Aust Orthod J. 2009 May;25(1):1-7.

18. Evans LB, Powers JM. Factors affecting in vitro Bond strength of no-mix orthodontic cements. Am J Orthod. 1985 Jun; 87(6):508-12.

19. Di Nocoló R, Araújo MAM, Alves LAC, Assunção RO, Rocha DM. Shear bond strength of orthodontic brackets bonded using halogen light and light-emitting diode at different debond times. Braz Oral Res. 2010 Jan-Mar;24(1):64-9.

20. Francisconi PAS, Souza CS, Scucuglia LR, Rosa HM. Influência da termociclagem na análise da resistência ao cisalhamento do cimento de ionômero de vidro (Fuji Otho Lc) e da resina composta (Concede Ortodôntico) utilizados na colagem de bráquetes ortodônticos. Rev Fac Odontol Bauru. 2000 JulDez;8(3/4):9-14

21. Reynolds IR. A review of direct orthodontic bonding. Br J Orthod. 1975 Apr;2(3):171-8.

22. Lugato ICPT, Pignatta LMB, Arantes FM, Santos ECA. Comparison of the shear bond strengths of conventional mesh bases and sandblasted orthodontic bracket bases. Braz Oral Res. 2009 Oct-Dec;23(4):407-14. 
23. Park SB, Son WS, Ko CC, García-Godoy F, Park MG, Kim $\mathrm{HI}$, et al. Influence of flowable resins on the shear bond strength of orthodontic brackets. Dent Mater J. 2009 Nov;28(6):730-4.
24. Ødegaard J, Segner D. Shear bonding strength of metal brackets compared with a new ceramic bracket. Am J Orthod Dentofacial Orthop. 1988 Sep;94(3):201-6. 